\title{
Nutrient redistribution by grazing cattle drives patterns of topsoil $N$ and $P$ stocks in a low-input pasture ecosystem
}

\author{
Hans Schnyder $\cdot$ Felix Locher $\cdot$ Karl Auerswald
}

Received: 23 May 2009/Accepted: 27 November 2009/Published online: 12 December 2009

(C) Springer Science+Business Media B.V. 2009

\begin{abstract}
Nutrient cycles in grassland often involve net transfers from some areas to others. Here, we analyse patterns of $\mathrm{N}$ and $\mathrm{P}$ transfers by cattle in two grazing periods, and their relationships to soil $\mathrm{P}$ and $\mathrm{N}$ stocks in an unfertilised old pasture with a history of $>50$ years grazing. Net transfers were assessed from spatial patterns of nutrient ingestion and excretion. Total soil $\mathrm{N}$ and $\mathrm{P}$ were determined at $0-5,5-10,10$ 30 and $30-60 \mathrm{~cm}$. All analyses were performed with a spatial resolution of $10 \times 10 \mathrm{~m}^{2}$ or higher. Data were geostatistically interpolated. Nutrients accumulated in the flat crest zone and were depleted in the steeper areas. Nutrient ingestion was less and excretion higher in the accumulation zone (and vice versa in the depletion zone) revealing that both components of grazer-driven net transfers of nutrients promoted the development of accumulation/depletion zones. Topsoil stocks of $\mathrm{N}$ and $\mathrm{P}$ were closely correlated with excreta density and net transfers of $\mathrm{N}(P<0.001)$, whereas $\mathrm{N}$ and $\mathrm{P}$ at $30-60 \mathrm{~cm}$ displayed only weak or no correlation. Redistribution involved a small
\end{abstract}

H. Schnyder $(\bowtie) \cdot$ F. Locher $\cdot$ K. Auerswald

Lehrstuhl für Grünlandlehre,

Technische Universität München, Am Hochanger 1,

85350 Freising-Weihenstephan, Germany

e-mail: schnyder@wzw.tum.de

Present Address:

F. Locher

Wessling Laboratorien GmbH, Umweltanalytik München,

Forstenrieder Strasse 8-14, 82061 Neuried, Germany fraction of the soil stocks: nutrients grazed in two periods were equivalent to $0.8 \%$ of $\mathrm{N}$ and $0.2 \%$ of $\mathrm{P}$ of the whole pasture $(0-60 \mathrm{~cm})$. These factors suggest that topsoil nutrient distribution was modified by long-term stable patterns of net transfers of nutrients. The excess of $\mathrm{N}$ in the accumulation zone $(\mathrm{N}$ in accumulation zone minus $\mathrm{N}$ in depletion zone, in 0 $60 \mathrm{~cm}$ ) was 11 times larger than that of annual (i.e. short-term) net transfers; but for $\mathrm{P}$, it was 30 times larger. This contrast likely derived from leaching/ volatilization losses of $\mathrm{N}$ in the accumulation zone and only small inputs of biologically fixed $\mathrm{N}$ in the depletion zone. The nitrogen status of vegetation (Nitrogen Nutrition Index) had a strong effect on herbage production throughout the pasture, while the Phosphorus Nutrition Index indicated no limitation, except in urine patches.

Keywords Net primary production (NPP) . Geostatistics · Grazing behaviour - Leaf area index . NNI - Nitrogen volatilization and leaching .

Nutrient balance $\cdot$ Nutrient losses - Spatial pattern · Vegetation composition

\section{Introduction}

Nitrogen (N) and phosphorus (P) are the mostcommonly growth-limiting nutrients in grassland ecosystems (Clark 1977; Risser and Parton 1982) 
and important determinants of patterns in species composition and richness (Ellenberg 1996; Marini et al. 2007). Large herbivores, such as cattle, play a dominant role in the cycling of $\mathrm{N}$ and $\mathrm{P}$ in pastures (Floate 1981; Williams and Haynes 1990; Haynes and Williams 1993; Rotz et al. 2005). They ingest large quantities of $\mathrm{N}$ and $\mathrm{P}$ by grazing, but return 70 $90 \%$ of these nutrients to the pasture via excreta deposition (Whitehead 2000). Redistribution of nutrients via excretion is spatially heterogeneous (Hirata et al. 1987; White et al. 2001; Jewell et al. 2007; Auerswald et al. 2009). Augustine and Frank (2001) noted that large herbivores altered the distribution of soil $\mathrm{N}$ at every spatial scale from that of single plants to that of the landscape. Such heterogeneity is related to (at least) three different factors. Firstly, in one grazing cycle, nutrients are removed from almost all parts of the pasture, but excretal returns cover only a fraction of the pasture area (=nutrient concentration). Secondly, much of the $\mathrm{N}$ is excreted in urine, but almost all $\mathrm{P}$ is returned with dung (Haynes and Williams 1993), causing separation of $\mathrm{N}$ and $\mathrm{P}$ returns at least at low spatial scales (=nutrient separation). Thirdly, topography or other site conditions can exert differential effects on grazing and excretion behaviour, leading to zonal heterogeneity in nutrient distribution (Jewell et al. 2007; Auerswald et al. 2009) (=landscape-scale nutrient redistribution). Cows usually prefer flat zones as campsites and visit more inclined zones only for grazing (Gillingham et al. 1980; Arnold 1981; Rowarth et al. 1992; Jewell et al. 2007). However, abiotic factors such as geomorphic and fluvial processes can also create topographic variation in soil organic matter and nutrient stocks (Jenny 1980; Burke et al. 1999; Augustine and Frank 2001), potentially modifying the effect of large herbivores on soil nutrient distribution in grazed landscapes. Moreover, spatial variation of leaching and volatilisation losses (Wachendorf et al. 2005), or inputs by $\mathrm{N}_{2}$ fixation (Hansen et al. 2002) may modify the pattern of soil nitrogen stocks. Therefore, the actual correspondence between (short-term) nutrient transfer patterns created by grazers and soil stocks of nutrients may be less obvious for $\mathrm{N}$ (than $\mathrm{P}$ ) and complicate the interpretation of cause-effect relations between $\mathrm{N}$ redistribution and soil $\mathrm{N}$ stocks.

In this work, we assess the role of cattle in generating paddock-scale patterns of soil $\mathrm{N}$ and $\mathrm{P}$ stocks. $\mathrm{N}$ and $\mathrm{P}$ were chosen because they are the most-commonly growth-limiting nutrients of extensively managed pastures, their transfers are potentially uneven and patterns of $\mathrm{N}$ may be modified/ attenuated (relative to $\mathrm{P}$ ) by other processes (see above). Accordingly, contrasts between $\mathrm{P}$ and $\mathrm{N}$ stocks in accumulation and depletion zones might reveal the cumulative effect of these (secondary) processes on N stocks (Augustine 2003). The study was conducted in an extensively managed pasture paddock in the tertiary hill country ('Tertiärhügelland') of Southern Germany. This paddock was previously used to map dung and urine distribution in different seasons over several years, and demonstrated consistent long-term spatial patterns of excreta returns in these years (and in the year of the present study) (Auerswald et al. 2009). Accordingly, we tested the predictions that (1) the pattern of soil nutrient stocks in the topsoil should reflect the patterns of $\mathrm{N}$ and $\mathrm{P}$ redistribution by cattle, supporting the hypothesis that cattle-driven redistribution of nutrients is conservative, leading to long-term buildup of larger stocks in the accumulation zone and loss in the depletion zone, (2) the pattern of topsoil nutrient stocks should differ from that at depth, which should be more even across the landscape or unrelated to grazer driven nutrient transfers (Augustine 2003), and (3) accumulation/depletion zones should show larger contrasts for $\mathrm{P}$ than $\mathrm{N}$ because of secondary effects (see above). Thus, we analyzed the spatial distribution of soil $\mathrm{N}$ and $\mathrm{P}$ stocks (at 4 depths), and $\mathrm{N}$ and $\mathrm{P}$ ingestion by grazing and return by excretion in two grazing cycles of 1 year. These analyses were performed with a spatial resolution of $10 \times 10 \mathrm{~m}^{2}$ or higher. As secondary objectives, we determined the relationship between sward $\mathrm{N}$ and $\mathrm{P}$ status and herbage production (Lemaire and Gastal 1997; Lemaire and Salette 1984) and the effects of soil nutrient status on herbage production and vegetation composition.

\section{Materials and methods}

Study site

Data were collected in 1996 on a pasture in the Tertiärhügelland in Southern Germany. The mean annual precipitation at the site averages $834 \mathrm{~mm}$, the 


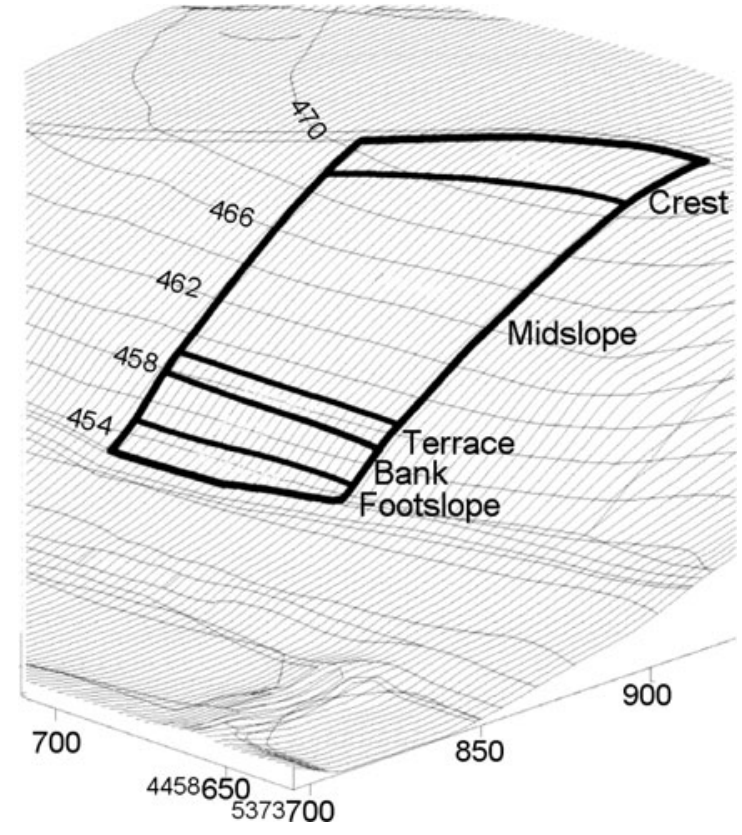

Fig. 1 Topography of pasture (0.64 ha). Axes are GaussKrüger coordinates, height is in $\mathrm{m}$ a.s.l. Five zones with different slope gradients are delineated. Note the orientation of the figure

mean annual air temperature is $8.4^{\circ} \mathrm{C}$ (1994-2001) and the soil is a Dystric Eutrochrept. The landscape is hilly with sandy soils on the hill tops and loamy loess covering the slopes and valleys (Sinowski and Auerswald 1999). The paddock (0.64 ha) has been used as a pasture for at least 50 years, was not fertilized for at least 10 years preceding the study, and was located on a north-facing slope (Fig. 1). The southern limit was situated at the rim of a plateau (flat crest), at about $472 \mathrm{~m}$ height above sea level (a.s.l.). The northern limit was situated at the footslope, at about $453 \mathrm{~m}$ a.s.l. The slope gradient was relatively shallow in the south (4\%) and increased towards the north (maximum 18\%) with a flatter terrace in between. Thus, the pasture was divided into five zones, which are further referred to as crest, midslope, terrace, bank and footslope, from south to north, with mean slope gradients of 4, 11, 9, 18 and $9 \%$ (Fig. 1).

The pasture was grazed rotationally, with three grazing periods in 1996, according to traditional management. The first and second grazing periods of 1996 (31 May to 2 June, and 26 to 28 June) formed the object of the present study. No rain was recorded during both grazing periods and the mean daily temperature was 18 and $15^{\circ} \mathrm{C}$. Animals had free access to a water station which was located outside the paddock and could be visited through an open gate in the NE corner of the paddock. There were no buildings or trees which might have offered shade and thus influenced the behaviour of the grazing herd. The herd consisted of 30 suckler cows of the Deutsches Fleckvieh breed, one Angus bull and about 15 calves.

\section{Soil analysis}

In November 1996 soil samples were taken at 67 locations in the pasture. Sampling occurred in a regular grid with a mesh size of $10 \times 10 \mathrm{~m}^{2}$, and in 4 depths: $0-5,5-10,10-30$ and 30-60 cm. At each location eight subsamples were taken in an area of approx. $1 \mathrm{~m}^{2}$. Samples were collected with a screw auger of $5 \mathrm{~cm}$ diameter and mixed. The samples were divided into two parts: one part was immediately frozen until further analysis for mineral $\mathrm{N}$ components. The other part was air dried until constant weight and analysed for total N. Plant parts such as big roots were removed from the samples.

For the analysis of total $\mathrm{N}$ the air dried aggregates were crushed in a mortar and then passed through a $2 \mathrm{~mm}$ sieve. Stone content ( $>2 \mathrm{~mm}$ ) was negligible. The sieved material was ground with a ball mill. $\mathrm{N}$ was determined with an elemental analyser (Carlo Erba EA 1110, Milano, Italy). Mineral (soluble) N fractions $\left(\mathrm{NO}_{3}{ }^{-}\right.$and $\left.\mathrm{NH}_{4}{ }^{+}\right)$were extracted with $\mathrm{CaCl}_{2}$ and analysed after fractionation and distillation (Official laboratory manual of the Association of German Agricultural Research Stations, VdLUFA 1991).

For $\mathrm{P}$ analysis, the soil was extracted with aqua regia $\left(\mathrm{HNO}_{3}: \mathrm{H}_{2} \mathrm{SO}_{4}=1: 3\right)$, then diluted in ammonia heptamolybdate and measured photometrically at $578 \mathrm{~nm}$. This fraction, defined as total $\mathrm{P}$, comprises organic and mineral $\mathrm{P}$ with the exception of $\mathrm{P}$ which is strongly fixed in minerals (VdLUFA 1991). Plant available $\mathrm{P}\left(\mathrm{P}_{\mathrm{CAL}}\right)$ was extracted with calcium acetate lactate and measured photometrically at $882 \mathrm{~nm}$ after reaction with ammonium molybdate (VdLUFA 1991). Soil bulk density was determined from $100 \mathrm{~cm}^{3}$ soil cores according to Hartge and Horn (1989) and yielded $1.3 \mathrm{~g} \mathrm{~cm}^{-3}$ at $0-10 \mathrm{~cm}$ depth, and $1.47 \mathrm{~g} \mathrm{~cm}^{-3}$ at $10-60 \mathrm{~cm}$ depth. The $\mathrm{N}$ and $\mathrm{P}$ 
concentrations (g per g dry soil) were multiplied with bulk density and depth, to obtain the stock size per unit area $\left(\mathrm{g} \mathrm{m}^{-2}\right)$.

Vegetation sampling and analysis

Standing aboveground biomass above a stubble height of $5 \mathrm{~cm}$ was sampled one day before and immediately after each grazing period in 1996. Pregrazing biomass samples of $2 \mathrm{~m}^{2}$-plots were collected from 58 locations $\left(10 \times 10 \mathrm{~m}^{2}\right.$ grid $)$ in the first grazing period and 120 locations $\left(10 \times 5 \mathrm{~m}^{2}\right.$ grid) in the second grazing period. Post-grazing samples were obtained with lower spatial resolution, i.e. at 28 in the first and 55 sites in the second grazing period.

Samples were oven dried at $60^{\circ} \mathrm{C}$ for $72 \mathrm{~h}$, weighed and ground for analysis of plant tissue $\mathrm{N}$ with an elemental analyser (Carlo Erba EA 1110, Milano, Italy). For plant $\mathrm{P}$ analysis, the tissue was combusted with $\mathrm{H}_{2} \mathrm{SO}_{4}$, diluted in a vanadatemolybdate reagent and measured photometrically at $430 \mathrm{~nm}$ (VdLUFA 1991).

Leaf area index

The leaf area index of vegetation at each sampling location was estimated using a LAI 2000 plant canopy analyzer (LI-COR Inc., Lincoln, NE, USA). Measurements were taken immediately before sample harvests in both growth periods.

\section{Botanical composition}

The botanical composition of the pasture was determined by the Braun-Blanquet method (Braun-Blanquet 1964). For this, the occurrence of all plant species in the pasture paddock was assessed in contiguous quadrats of $10 \times 10 \mathrm{~m}^{2}$ in the spring of 1996 .

\section{Excreta distribution}

Excreta distribution was assessed during the first grazing period (May 1996). This happened to be a full moon period which allowed continuous observation of the cattle for three days to monitor the exact spatial and temporal pattern of all dung and urine depositions (for details see Auerswald et al. 2009). All excreta were mapped tacheometrically. Thiessen polygons were calculated from the coordinates of the excreta with ArcView ${ }^{\mathrm{TM}}$ (Esri, Kranzberg, Germany, 1996) extension "thiessen.avx". Thiessen polygons were then gridded (cell size $0.5 \mathrm{~m}$ ) and the average thiessen area calculated for each $5 \times 5 \mathrm{~m}^{2}$ block (see "Statistics and geostatistics", below). Excreta density was calculated as the inverse of the average thiessen polygon area of each block. Excreta distribution observed in other years and seasons was very similar to the distribution in May 1996 (Auerwald et al. 2009), so that the geostatistically interpolated and therefore smoothed data provided a robust estimate of the local long-term mean excreta density. Total excreta density (=the sum of urine spot and dung patch densities) and dung density (=the density of dung patches, only) were calculated separately.

Nitrogen and phosphorus nutrition status of vegetation (NNI and $\mathrm{PNI}$ )

The nitrogen status of each pre-grazing biomass sample was assessed by its' Nitrogen Nutrition Index (NNI) as defined by Lemaire and Gastal (1997; see also Lemaire and Salette 1984 and Duru et al. 1997):

$\mathrm{NNI}=\mathrm{N}_{\text {act }} / \mathrm{N}_{\text {crit }}$,

where $\mathrm{N}_{\text {act }}$ denotes the $\mathrm{N}$ concentration in aboveground dry matter biomass $\left(\mathrm{g}(100 \mathrm{~g})^{-1}\right)$, and $\mathrm{N}_{\text {crit }}$ is the critical $\mathrm{N}$ concentration estimated as

$\mathrm{N}_{\text {crit }}=4.8 \mathrm{~W}^{-0.32}$,

with $\mathrm{W}$ the pre-grazing dry matter biomass of the same sample $\left(\mathrm{t} \mathrm{ha}{ }^{-1}\right)$. The Phosphorus Nutrition Index (PNI) was calculated as: $\mathrm{PNI}=100(\mathrm{P} \% /$ $(0.15+0.065 \mathrm{~N} \%)$ ), with $\mathrm{P} \%$ and $\mathrm{N} \%$ the percent $\mathrm{P}$ and $\mathrm{N}$ in aboveground dry matter (Duru and Ducroq 1997).

The assessment of NNI and PNI did not account for (or ignored) heterogeneity of nutrient status within a sample, which could have resulted from the presence of legumes or a urine spot inside the sampled area $\left(1 \mathrm{~m}^{2}\right)$.

Statistics and geostatistics

Univariate statistics of soil and vegetation variables were calculated with JMP software Version 4.0.2 (SAS Institute Inc., Cary, NC, USA). Relations among variables were analysed with simple least 
squares regressions. Interpolations were performed with geostatistical techniques (e.g. Webster 1985) using the GS+ program (GS+/23, Professional Version 2.3c, Gamma Design Software 1990-1995, Plainwell, Michigan, USA). Ordinary block kriging $\left(5 \times 5 \mathrm{~m}^{2}\right.$ blocks, 12 nearest neighbours) was performed to generate estimates for all parameters at 192 predefined orthogonal coordinates. This enabled the direct comparison of parameters which could not be assessed at the same position in the pasture because they were obtained by destructive sampling (soil sampling, initial and residual biomass) or could not be set on predefined coordinates (excreta). In the definition of the 192 blocks those laying at the edge of the paddock were omitted for two reasons: (1) Kriging error increased sharply beyond the area of sampling and considerably raised the overall error because another row of blocks at the edge would have added 59 more blocks. (2) Soil and vegetation sampling was not carried out with sufficient spatial resolution to catch the fence effect, which was most pronounced in the first meters along the fence (Auerswald et al. 2009). Thus, the analysis accounted for the topography effect but not for the fence effect identified in the excreta pattern (Auerwald et al. 2009). After the interpolation, data were exported to $\mathrm{ArCView}^{\mathrm{TM}}$ for further analyses.

The interpolated data were chosen for presentation and correlation analysis, because this reduced the leverage effect of single extreme values on correlations. Further, it allowed comparison of all data with the same spatial grid.

Nutrient ingestion, excretion and net transfer

The principles for calculation of regionalised net nutrient transfers are illustrated in Fig. 2. The grazerdriven, block-specific net transfer of $\mathrm{N}\left(\mathrm{N}_{\text {transfer }} \mathrm{ij}\right)$ was calculated as the difference between blockspecific $\mathrm{N}$ excretion $\left(\mathrm{N}_{\text {excretion }} \mathrm{ij}, \mathrm{g} \mathrm{m}^{-2}\right)$ and $\mathrm{N}$ ingestion ( $\mathrm{N}_{\text {ingestion } \mathrm{ij}}, \mathrm{g} \mathrm{m}^{-2}$ ),

$\mathrm{N}_{\text {transfer ij }}=\mathrm{N}_{\text {excretion ij }}-\mathrm{N}_{\text {ingestion ij }}$,

with $\mathrm{i}$ and $\mathrm{j}$ representing the $\mathrm{x}$ and $\mathrm{y}$ coordinates of the block. $\mathrm{N}$ ingestion by the cattle was obtained from standing dry biomass before grazing $\left(\mathrm{W}_{\text {pre ij }}\right)$ and after grazing $\left(\mathrm{W}_{\text {post } \mathrm{ij}}\right)$ (in $\mathrm{g} \mathrm{m}^{-2}$ ) and $\mathrm{N}$ concentration in dry matter $\left(\mathrm{g} \mathrm{g}^{-1}\right)$ of pre- and post-grazing biomass $\left(\mathrm{N}_{\text {pre ij }}\right.$ and $\mathrm{N}_{\text {post }}$ ij $)$ as:
$\mathrm{N}_{\text {ingestion ij }}=\left(\mathrm{W}_{\text {pre ij }} \times \mathrm{W}_{\text {pre ij }}\right)-\left(\mathrm{W}_{\text {post ij }} \times \mathrm{N}_{\text {post ij }}\right)$.

This procedure (eq. 4) accounted for selective grazing by cattle, and thus for effects of vegetation pattern and herbage nutrient concentration patterns on nutrient ingestion. P ingestion was calculated accordingly.

For estimation of total nutrient excretions $\left(\mathrm{N}_{\text {total }}\right.$ excretion, g paddock $^{-1}$ grazing period $^{-1}$ ) we assumed that $20 \%$ of the ingested $\mathrm{P}$ and $\mathrm{N}$ were retained in the animals, so that $80 \%$ of total nutrient ingestion $\left(\mathrm{N}_{\text {total }}\right.$ ingestion, $\mathrm{g}$ paddock $^{-1}$ grazing period $^{-1}$ ) was returned to the pasture (Whitehead 2000):

$\mathrm{N}_{\text {total excretion }}=0.8 \times \mathrm{N}_{\text {total ingestion }}$.

The $\mathrm{N}$ excretion in each $5 \times 5 \mathrm{~m}^{2}$ block was obtained by multiplying the total $\mathrm{N}$ excretion $\left(\mathrm{N}_{\text {total }}\right.$ excretion, $\mathrm{g}$ paddock $^{-1}$ grazing period ${ }^{-1}$ ) in the pasture by the fraction of excreta $\left(f_{\text {excretion }} \mathrm{ij}=\right.$ number of excreta patches in block ij/total number of excreta patches in the paddock; excreta $=$ dung + urine) deposition in a given block:

$\mathrm{N}_{\text {excretion ij }}=\mathrm{f}_{\text {excretion ij }} \times \mathrm{N}_{\text {total excretion }}$.

Thus, we assumed that all excreta patches contained the same amount of $\mathrm{N}$ irrespective of the location where they were deposited. This assumption seems justified: digesta are mixed in the rumen and animals moved across the pasture several times during a grazing period.

Local $\mathrm{P}$ excretion was obtained by multiplying with the fraction of dung depositions, as virtually all $\mathrm{P}$ excretion occurs in dung (Haynes and Williams 1993).

All calculations were made using block-kriged primary data (see above). The short-term balances of nutrient ingestion and excretion (=net transfers) were used to localize and delimit the areas of (current) grazerdriven nutrient accumulation and depletion. The zone of depletion was defined as those blocks which belonged to the lowest quartile of both $\mathrm{N}$ and $\mathrm{P}$ net transfer. Conversely, the accumulation zone included the blocks inside the highest quartile of both $\mathrm{N}$ and $\mathrm{P}$ net transfer.

\section{Results}

Soil nutrient stocks

Nutrient stock sizes in the topsoil $(0-5 \mathrm{~cm})$ varied strongly (Fig. 3): Volumetric $\mathrm{N}$ concentration ranged 

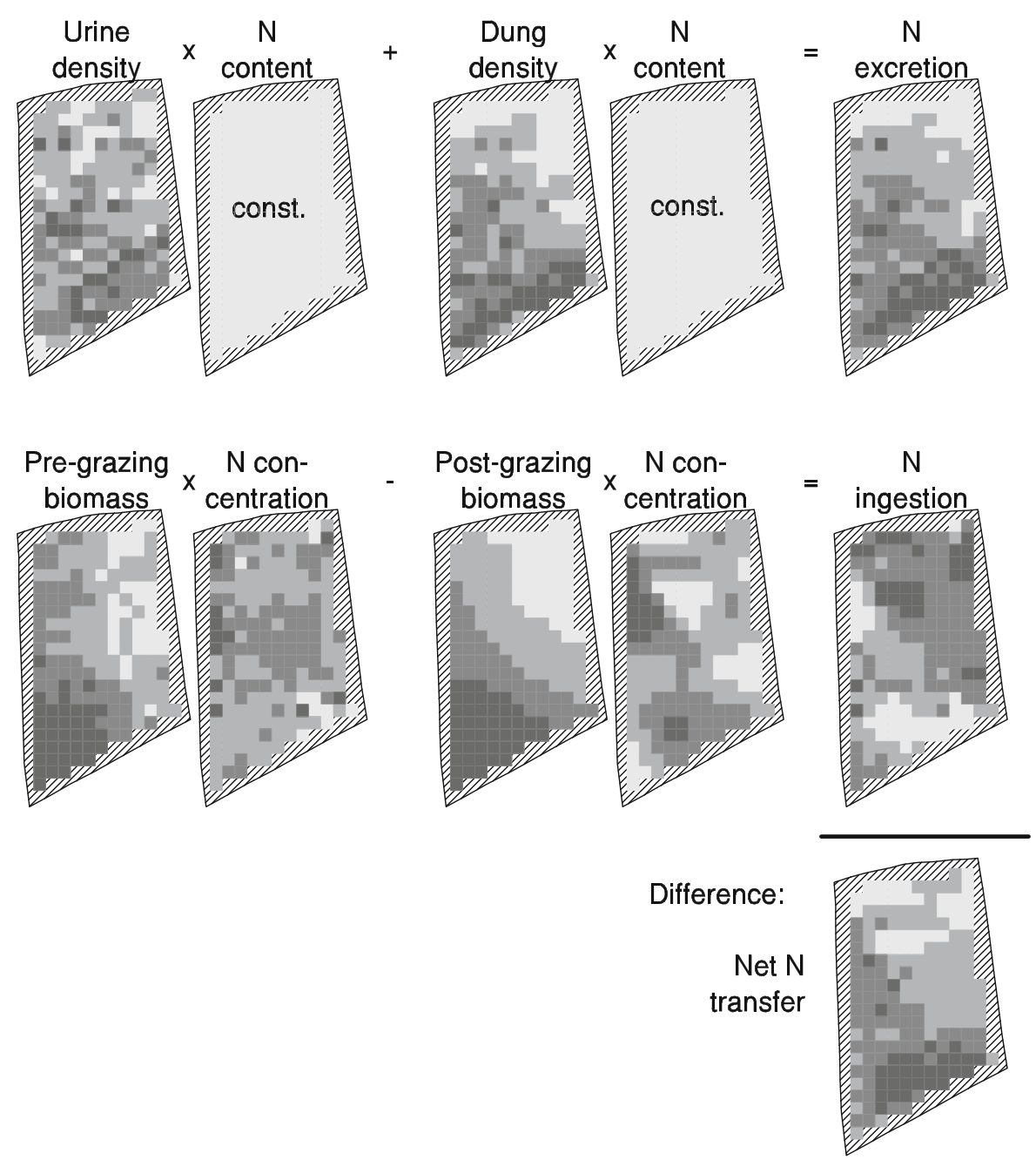

Fig. 2 Illustration of methodology for calculation of regionalised net $\mathrm{N}$ transfers. Net $\mathrm{N}$ transfer was obtained as the difference of (block-specific) nutrient excretion and ingestion. $\mathrm{N}$ ingestion in a specific block was calculated from block-specific pre- and postgrazing biomass and nutrient contents. Nutrient excretion was obtained from block-specific excreta density (urine + dung) and the average nutrient content of single excreta patches. For calculation of the latter, we assumed that $80 \%$ of all ingested $\mathrm{N}$ and $\mathrm{P}$ was returned to the pasture, and nutrient content per excretion patch was the same in urine and dung everywhere in the pasture (see "Materials and methods"). Urine deposition was not considered when calculating $\mathrm{P}$ excretion, since all $\mathrm{P}$ is returned in dung. The

between 3.2 and $10.0 \mathrm{~kg} \mathrm{~m}^{-3}$ soil, and $\mathrm{P}$ concentration varied from 1.0 to $2.0 \mathrm{~kg} \mathrm{~m}^{-3}$. Lower concentrations were found at greater depth: $\mathrm{N}$ concentration varied from 0.8 to $1.5 \mathrm{~kg} \mathrm{~m}^{-3}$ at $30-60 \mathrm{~cm}$, and $\mathrm{P}$ concentration ranged between 0.6 and $0.9 \mathrm{~kg} \mathrm{~m}^{-3}$. Also, the soil N/P (w/w) ratio varied with depth; it averaged 4.3 in $0-5 \mathrm{~cm}$ and decreased to 1.6 in $30-\mathrm{z} 60 \mathrm{~cm}$. maps show the results for $\mathrm{N}$ in the 1st grazing period. The shades of grey denote four classes as defined by the mean and standard deviation. Very light grey is smaller than the mean minus one SD, light grey represents the range between the mean and minus one SD of the mean, dark grey gives the range between the mean and plus one $\mathrm{SD}$, very dark grey represents values exceeding the mean plus one SD. Note that this does not imply uniform importance and variation as the means and the standard deviations of the individual variables differ considerably; e.g. post-grazing biomass varied much more than pre-grazing biomass and hence influences had a bigger effect on the pattern of biomass ingestions. In the present case dung density had the strongest impact on the final map

Spatial (i.e. zonal) variation of nutrient stocks was non-uniform (Fig. 3), but $\mathrm{P}$ and $\mathrm{N}$ presented similar distributions. Thus, $\mathrm{N}$ and $\mathrm{P}$ concentration were closely correlated at each depth and across depths (Table 1). This was true except for the pattern of $\mathrm{N}$ in the top $5 \mathrm{~cm}$, which was unrelated to that of P below $30 \mathrm{~cm}$. Also, $\mathrm{N}$ in the top $5 \mathrm{~cm}$ was unrelated to $\mathrm{N}$ below $30 \mathrm{~cm}$ (Table 2). 


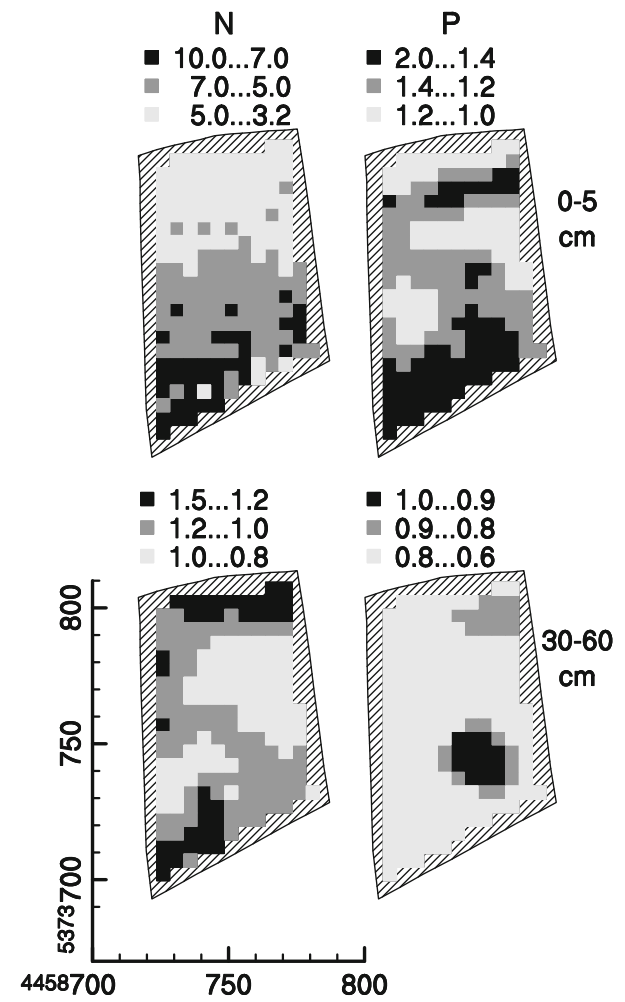

Fig. 3 Maps of volumetric soil $\mathrm{N}$ (left column) and $\mathrm{P}$ concentrations (right column) in 0-5 (top row) and 30-60 cm depth (bottom row) in blocks of $5 \times 5 \mathrm{~m}^{2}$. Different shades denote different classes of nutrient concentration, given in $\mathrm{kg} \mathrm{m}^{-3}$ (see Figure for range associated with each class). Data were obtained by interpolation of data from 67 soil samples taken in a regular grid of $10 \times 10 \mathrm{~m}^{2}$ (see "Materials and methods"). Axes give Gauss-Krüger coordinates

The $\mathrm{N}$ stock in $0-5 \mathrm{~cm}$ was largest in the flat crest zone and stock size decreased with decreasing altitude $\left(r^{2}=0.61, P<0.001\right)$ and with increasing slope $\left(r^{2}=0.15, P<0.001\right)$ (Fig. 3$)$. This pattern was less apparent at depth: at $30-60 \mathrm{~cm}$ relatively large stocks were also found in the bank and footslope region (Figs. 1, 2).

The pattern of $\mathrm{P}$ in $0-5 \mathrm{~cm}$ was similar to that of $\mathrm{N}$ : it showed highest values in the crest zone and stocks were decreasing with decreasing altitude $\left(r^{2}=0.51, \quad P<0.001\right)$ and increasing slope $\left(r^{2}=0.20, P<0.001\right)$. Again, however, the $\mathrm{P}$ stock below $30 \mathrm{~cm}$ was only weakly related to that in 0 $5 \mathrm{~cm}$ (Table 2), and varied relatively little.

The N/P ratio in topsoil (Table 3) also exhibited spatial variation: it was highest in the crest zone and lowest in the footslope area (data not shown, but see Table 4). Again, this pattern was not evident below $30 \mathrm{~cm}$.
Net nutrient transfer

The net transfers of $\mathrm{N}$ and $\mathrm{P}$ by the grazing cattle were positive in about $30 \%$ of the paddock. The highest surpluses corresponded to $15 \mathrm{~g} \mathrm{~m}^{-2}$ for $\mathrm{N}$ and $1.5 \mathrm{~g} \mathrm{~m}^{-2}$ for $\mathrm{P}$; the largest deficits amounted to $-11 \mathrm{~g} \mathrm{~m}^{-2}$ for $\mathrm{N}$ and $-1.5 \mathrm{~g} \mathrm{~m}^{-2}$ for $\mathrm{P}$ (Fig. 4). Thus, animal-driven nutrient transfers caused large discrepancies in nutrient balance between different zones of the pasture. The maximum net transfer of $\mathrm{N}$ was $26 \mathrm{~g} \mathrm{~m}^{-2}$ and that of $\mathrm{P}$ was $3 \mathrm{~g} \mathrm{~m}^{-2}$ in only two grazing periods.

The net transfers of $\mathrm{N}$ and $\mathrm{P}$ were closely correlated with stock sizes of $\mathrm{N}$ and $\mathrm{P}$ in the topsoil $(0-30 \mathrm{~cm})$ (Table 2). Net $\mathrm{N}$ transfer and $\mathrm{N}$ stock size below $30 \mathrm{~cm}$ also showed some degree of similarity, but P stock size below $30 \mathrm{~cm}$ was unrelated to net transfer of $P$.

Notably, net transfers of $\mathrm{N}$ and $\mathrm{P}$ were tightly correlated with total excreta density and dung density respectively (Table 2), indicating that excretion was the dominant component of net transfers. Mean excreta density and dung density were six times higher in the crest zone than in the footslope zone and declined gradually along the hill reaching lowest densities in the deeper northern part (footslope and bank, Fig. 2) of the paddock (Auerswald et al. 2009). Excreta density increased with altitude $(r=0.72)$ and decreased with slope angle $(r=-0.54)$.

Depletion and accumulation zones

The spatial patterns of $\mathrm{N}$ and $\mathrm{P}$ net transfers were very similar, demonstrating the existence of common zones of $\mathrm{N}$ and $\mathrm{P}$ depletion and accumulation (Figure 4). Proper zones of strong N and P depletion were defined as those blocks which belonged to the lowest quartile of both $\mathrm{N}$ net transfer and $\mathrm{P}$ net transfer. These lost $>6.6 \mathrm{~g} \mathrm{~m}^{-2} \mathrm{~N}$ and $>0.8 \mathrm{~g} \mathrm{~m}^{-2} \mathrm{P}$ in two consecutive grazing periods. Conversely, blocks in the uppermost quartile were assigned to the accumulation zone. These received $>1.1 \mathrm{~g} \mathrm{~m}^{-2} \mathrm{~N}$ and $>0.1 \mathrm{~g} \mathrm{~m}^{-2} \mathrm{P}$ in two grazing periods.

The accumulation and depletion zones had a similar size: both comprised about $15 \%$ of the total paddock area. The two zones differed in many parameters (Table 5), including floristic composition (Table 6). Of the total of 55 plant species present in the paddock, 52 were also present in the depletion zone, but only 38 in the accumulation zone (Table 6). Arrhenatherum elatius L., Galium mollugo L., and Geranium pratense 
Table 1 Correlation matrix (Pearson product moment correlation) between soil nutrient stocks at different depths

\begin{tabular}{lllll}
\hline & $\mathrm{N}$ in $0-5 \mathrm{~cm}$ & $\mathrm{~N}$ in $5-10 \mathrm{~cm}$ & $\mathrm{~N}$ in $10-30 \mathrm{~cm}$ & $\mathrm{~N}$ in $30-60 \mathrm{~cm}$ \\
\hline $\mathrm{P}$ in $0-5 \mathrm{~cm}$ & $0.48^{* * *}$ & $0.44^{* * *}$ & $0.35^{* * *}$ & $0.32^{* * *}$ \\
$\mathrm{P}$ in $5-10 \mathrm{~cm}$ & $0.16^{*}$ & $0.25^{* * *}$ & $0.32^{* * *}$ & $0.38^{* * *}$ \\
$\mathrm{P}$ in $10-30 \mathrm{~cm}$ & $0.39^{* * *}$ & $0.41^{* * *}$ & $0.50^{* * *}$ & $0.59^{* * *}$ \\
$\mathrm{P}$ in $30-60 \mathrm{~cm}$ & $0.00^{\mathrm{ns}}$ & $0.15^{*}$ & $0.39^{* * *}$ & $0.24 * *$ \\
\hline
\end{tabular}

Interpolated data of 192 grid blocks $\left(25 \mathrm{~m}^{2}\right)$ with identical coordinates were related to each other $n s$ non-significant

$* P<0.05, * * P<0.01, * * * P<0.001$

Table 2 Correlation matrix (Pearson product moment correlation) between excreta density, net nutrient transfer and soil nutrient stocks at different depths

\begin{tabular}{|c|c|c|c|c|c|}
\hline & Net $\mathrm{N}$ transfer & $\mathrm{N}$ in $0-5 \mathrm{~cm}$ & $\mathrm{~N}$ in $5-10 \mathrm{~cm}$ & $\mathrm{~N}$ in $10-30 \mathrm{~cm}$ & $\mathrm{~N}$ in $30-60 \mathrm{~cm}$ \\
\hline $\begin{array}{l}\text { Excreta density } \\
\quad \text { (urine and dung) }\end{array}$ & $0.96 * * *$ & $0.50 * * *$ & $0.36 * * *$ & $0.33 * * *$ & $0.07^{\mathrm{ns}}$ \\
\hline Net $\mathrm{N}$ transfer & & $0.49 * * *$ & $0.41 * * *$ & $0.44 * * *$ & $0.20 * *$ \\
\hline $\mathrm{N}$ in $0-5 \mathrm{~cm}$ & & & $0.49 * * *$ & $0.37 * * *$ & $0.02^{\mathrm{ns}}$ \\
\hline $\mathrm{N}$ in $5-10 \mathrm{~cm}$ & & & & $0.56^{* * *}$ & $0.34 * * *$ \\
\hline \multirow[t]{2}{*}{$\mathrm{N}$ in $10-30 \mathrm{~cm}$} & & & & & $0.62 * * *$ \\
\hline & Net $P$ transfer & $\mathrm{P}$ in $0-5 \mathrm{~cm}$ & $P$ in $5-10 \mathrm{~cm}$ & $P$ in $10-30 \mathrm{~cm}$ & $P$ in $30-60 \mathrm{~cm}$ \\
\hline Dung density & $0.85 * * *$ & $0.53 * * *$ & $0.27 * * *$ & $0.34 * * *$ & $-0.12^{\mathrm{ns}}$ \\
\hline Net $P$ transfer & & $0.49 * * *$ & $0.30 * * *$ & $0.37 * * *$ & $-0.01^{\mathrm{ns}}$ \\
\hline $\mathrm{P}$ in $0-5 \mathrm{~cm}$ & & & $0.82 * * *$ & $0.76 * * *$ & $0.18 * *$ \\
\hline$P$ in $5-10 \mathrm{~cm}$ & & & & $0.80 * * *$ & $0.34 * * *$ \\
\hline$P$ in $10-30 \mathrm{~cm}$ & & & & & $0.38 * * *$ \\
\hline
\end{tabular}

Interpolated data of 192 grid blocks $\left(25 \mathrm{~m}^{2}\right)$ with identical coordinates were related to each other

$n s$ non-significant

$* P<0.05, * * P<0.01, * * * P<0.001$

Table 3 Mean, standard deviation, minimum and maximum of nutrient net transfers and soil N/P ratios at different depths of 192 blocks $\left(25 \mathrm{~m}^{2}\right)$

\begin{tabular}{lcrrrr}
\hline & $N$ & Mean & SD & Min. & Max. \\
\hline Net N transfer $\left(\mathrm{g} \mathrm{m}^{-2}\right)$ & 192 & -2.3 & 5.2 & -11.1 & 15.3 \\
Net P transfer $\left(\mathrm{g} \mathrm{m}^{-2}\right)$ & 192 & -0.3 & 0.6 & -1.5 & 1.5 \\
N/P excreta & 192 & 9.1 & 3.7 & 5.0 & 28.9 \\
N/P soil 0-5 cm & 192 & 4.3 & 0.7 & 2.5 & 5.6 \\
N/P soil 5-10 cm & 192 & 3.4 & 0.2 & 2.9 & 3.8 \\
N/P soil 10-30 cm & 192 & 2.5 & 0.2 & 2.0 & 2.9 \\
N/P soil 30-60 cm & 192 & 1.6 & 0.2 & 1.2 & 2.0 \\
\hline
\end{tabular}

Interpolated data, see "Materials and methods"

L. were present in the accumulation zone, but absent from the depletion zone. Conversely, Cynosurus cristatus L., Deschampsia caespitosa L., Festuca rubra commutata L., Holcus mollis L. and Saxifraga granulata L. were present in the depletion zone, but absent from the accumulation zone.

The accumulation zone exhibited higher production than the depletion zone. Moreover, residual biomass after grazing was 2.4 (1st grazing) and 4 times (2nd grazing) higher in the accumulation zone than in the depletion zone, meaning that nutrient ingestion in the accumulation zone was less in relative $(\mathrm{N}$ and $\mathrm{P}$ ) and absolute terms ( $\mathrm{N}$; P ingestion was not statistically different in the two zones) (Table 5).

As expected the topsoil nutrient stocks differed strongly between the two zones. The $\mathrm{N}$ stock in 0 $10 \mathrm{~cm}$ was $29 \%$ larger, and the P stock was $25 \%$ larger in the accumulation zone. Also, the nitrate and $\mathrm{P}_{\mathrm{CAL}}$ stocks were 2.4 and 1.8 times larger in the accumulation than in the depletion zone. In total, the accumulation 
zone contained more total $\mathrm{N}$ (i.e. $+171 \mathrm{~g} \mathrm{~m}^{-2}$ ) than the depletion zone (Table 4). This excess was equivalent to approximately 11 times the cattle-driven $\mathrm{N}$ transfer from the depletion to the accumulation zone. The total P stock was $56 \mathrm{~g} \mathrm{~m}^{-2}$ larger, corresponding to approximately 30 times the $\mathrm{P}$ transfer.

Variability in nitrogen and phosphorus nutrition index (NNI and PNI)

The nitrogen nutrition index (NNI) of pasture vegetation was $<1.0$ in all parts of the pasture in both growth periods (Fig. 5, 2nd regrowth; data not shown for 1st

Table 4 Soil nutrient stocks ( $\mathrm{N}$ and $\mathrm{P}$ ), the $\mathrm{N} / \mathrm{P}$ ratio, $\mathrm{NO}_{3}$ and $\mathrm{P}_{\mathrm{CAL}}$ stocks, in the depletion and accumulation zones

\begin{tabular}{|c|c|c|}
\hline & $\begin{array}{l}\text { Depletion } \\
\text { zone }\end{array}$ & $\begin{array}{l}\text { Accumulation } \\
\text { zone }\end{array}$ \\
\hline $\mathrm{N} 0-5 \mathrm{~cm}\left(\mathrm{~g} \mathrm{~m}^{-2}\right)$ & $219 a$ & $320 \mathrm{~b}$ \\
\hline N 5-10 cm $\left(\mathrm{g} \mathrm{m}^{-2}\right)$ & $190 \mathrm{a}$ & $208 \mathrm{~b}$ \\
\hline $\mathrm{N} 10-60 \mathrm{~cm}\left(\mathrm{~g} \mathrm{~m}^{-2}\right)$ & $784 \mathrm{a}$ & 836 a \\
\hline $\mathrm{P} 0-5 \mathrm{~cm}\left(\mathrm{~g} \mathrm{~m}^{-2}\right)$ & $59 \mathrm{a}$ & $77 \mathrm{~b}$ \\
\hline P $5-10 \mathrm{~cm}\left(\mathrm{~g} \mathrm{~m}^{-2}\right)$ & $53 \mathrm{a}$ & $63 \mathrm{~b}$ \\
\hline P $10-60 \mathrm{~cm}\left(\mathrm{~g} \mathrm{~m}^{-2}\right)$ & 375 a & 403 a \\
\hline $\mathrm{N} / \mathrm{P}$ in soil $0-5 \mathrm{~cm}$ & $4.0 \mathrm{a}$ & $4.8 \mathrm{~b}$ \\
\hline $\mathrm{N} / \mathrm{P}$ in soil $5-10 \mathrm{~cm}$ & $3.4 \mathrm{a}$ & $3.4 \mathrm{a}$ \\
\hline $\mathrm{N} / \mathrm{P}$ in soil $10-60 \mathrm{~cm}$ & $2.1 \mathrm{a}$ & $2.1 \mathrm{a}$ \\
\hline $\mathrm{NO}_{3}$ in $0-60 \mathrm{~cm}\left(\mathrm{~g} \mathrm{~m}^{-2}\right)$ & $4.3 \mathrm{a}$ & $10.4 \mathrm{~b}$ \\
\hline $\mathrm{P}_{\mathrm{CAL}}$ in $0-60 \mathrm{~cm}\left(\mathrm{~g} \mathrm{~m}^{-2}\right)$ & $10.7 \mathrm{a}$ & $19.6 \mathrm{~b}$ \\
\hline
\end{tabular}

Different letters indicate significant differences between the zones $(P<0.05$, Tukey-Kramer test $)$ growth), indicating growth-limiting conditions of $\mathrm{N}$ supply everywhere in the pasture paddock. This was true except for fresh urine spots where $\mathrm{N}$ did not limit growth (data not shown). Conversely, the phosphorus nutrition index (PNI) was $>1.0$ everywhere, suggesting P-sufficient conditions (mean PNI of both grazings: 1.4; SD for both grazings: 0.1). Again fresh urine spots formed an exception: $\mathrm{P}$ usually limited growth in these locations (data not shown).

The spatial pattern of NNI was closely related to that of topsoil $\mathrm{N}$ concentration for concentrations lower than $8 \mathrm{~kg} \mathrm{~m}^{-3}\left(r^{2}=0.34 ; P<0.001\right)$ and net transfers of $\mathrm{N}$ lower than $+8 \mathrm{~g} \mathrm{~m}^{-2}\left(r^{2}=0.24\right.$; $P<0.001)$. NNI was least limiting in the flat crest region (Fig. 5, 2nd regrowth; data not shown for 1st growth), where topsoil stocks of $\mathrm{N}$ and net transfers of $\mathrm{N}$ were highest (compare with Figs. 2, 3). NNI was least in the more sloping areas in the northern part of the pasture (Fig. 5), where net transfers of $\mathrm{N}$ and topsoil stocks were also smallest (Figs. 2, 3).

Spatial patterns of NNI were well reflected in patterns of dry matter production $\left(r^{2}=0.23\right.$ and 0.65 for 1 st and 2nd growth; $P<0.001$ ) and leaf area index $\left(r^{2}=0.70\right.$ and 0.68 for 1 st and 2nd growth; $P<0.001$ ) (Fig. 5), corroborating the notion that pasture production was limited by $\mathrm{N}$.

\section{Discussion}

As far as we know, this is the first comparison of large-scale $(\geq 10 \mathrm{~m})$ net transfers of $\mathrm{N}$ and $\mathrm{P}$ by
Table 5 Parameters of net nutrient transfer in the depletion and accumulation zone

Different letters indicate significant differences between the zones $(P<0.05$, Tukey-Kramer test)

\begin{tabular}{lll}
\hline & Depletion zone & Accumulation zone \\
\hline Altitude [m] & 460 & 470 \\
Slope [\%] & 14 & 7 \\
Area [ha] & 0.045 & 0.055 \\
Pre-grazing biomass 1st growth $\left(\mathrm{g} \mathrm{m}^{-2}\right)$ & $329 \mathrm{a}$ & $378 \mathrm{~b}$ \\
Pre-grazing biomass 2nd growth $\left(\mathrm{g} \mathrm{m}^{-2}\right)$ & $268 \mathrm{a}$ & $346 \mathrm{~b}$ \\
Residual biomass 1st growth $\left(\mathrm{g} \mathrm{m}^{-2}\right)$ & $102 \mathrm{a}$ & $244 \mathrm{~b}$ \\
Residual biomass 2nd growth $\left(\mathrm{g} \mathrm{m}^{-2}\right)$ & $29 \mathrm{a}$ & $117 \mathrm{~b}$ \\
$\mathrm{~N}$ ingestion $\left(\mathrm{g} \mathrm{m}^{-2}\right)$ & $11.2 \mathrm{a}$ & $8.5 \mathrm{~b}$ \\
$\mathrm{P}$ ingestion $\left(\mathrm{g} \mathrm{m}^{-2}\right)$ & $1.4 \mathrm{a}$ & $1.2 \mathrm{a}$ \\
$\mathrm{N}$ excretion $\left(\mathrm{g} \mathrm{m}^{-2}\right)$ & $2.7 \mathrm{a}$ & $15.5 \mathrm{~b}$ \\
$\mathrm{P}$ excretion $\left(\mathrm{g} \mathrm{m}^{-2}\right)$ & $0.3 \mathrm{a}$ & $2.0 \mathrm{~b}$ \\
Net N transfer $\left(\mathrm{g} \mathrm{m}^{-2}\right)$ & $-8.4 \mathrm{a}$ & $7.0 \mathrm{~b}$ \\
Net P transfer $\left(\mathrm{g} \mathrm{m}^{-2}\right)$ & $-1.1 \mathrm{a}$ & $0.8 \mathrm{~b}$ \\
\hline
\end{tabular}



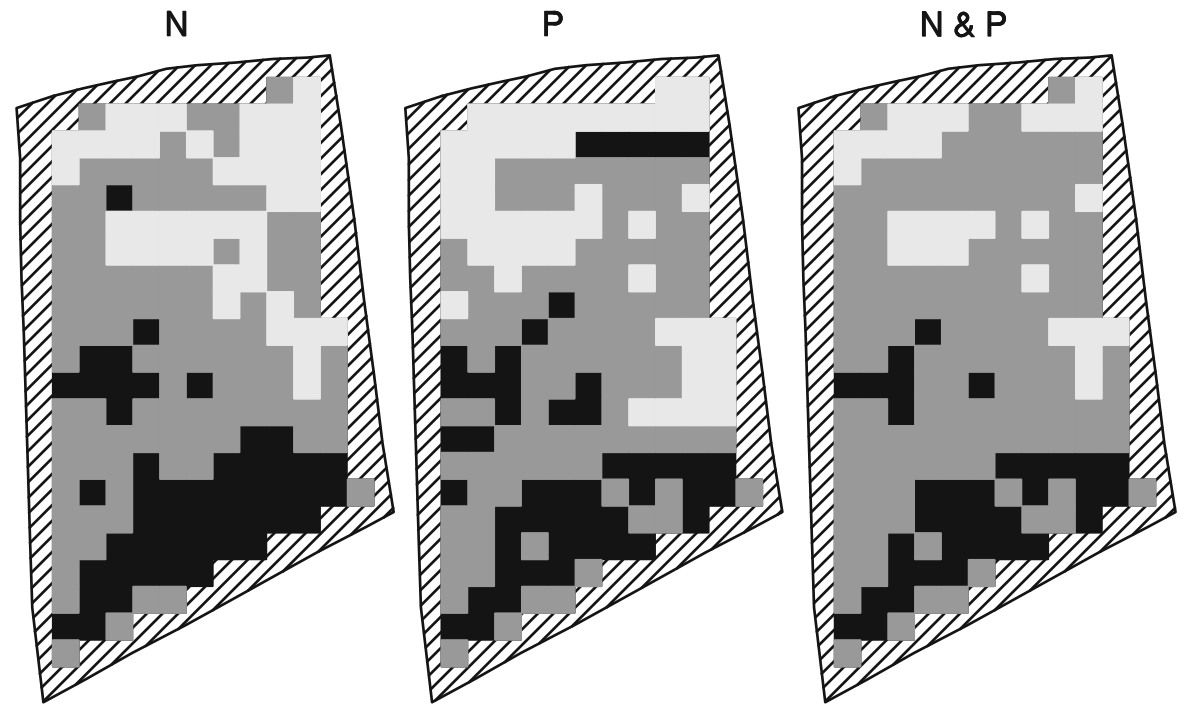

Fig. 4 Maps of net $\mathrm{N}$ transfer (left), net $\mathrm{P}$ transfer (middle), and depletion and accumulation zones (right map). Net transfers were determined for $5 \times 5 \mathrm{~m}^{2}$ blocks and were calculated as the difference between nutrient excretion and ingestion by cattle inside each block in two grazing periods. Different shades denote different net transfer classes. Black (positive net transfer, causing accumulation): 1 to $16 \mathrm{~g} \mathrm{~N} \mathrm{~m}^{-2}$, 0.1 to $1.5 \mathrm{~g} \mathrm{P} \mathrm{m}^{-2}$; dark grey (intermediate net transfer): -7 to

grazing cattle and soil $\mathrm{N}$ and $\mathrm{P}$ stocks in an entire pasture paddock. The analysis demonstrated strong correspondences between $\mathrm{N}$ transfers by cattle in two grazing periods and the spatial distribution of topsoil $\mathrm{N}$ stocks. The same was true for P. These correspondences are a necessary, but not sufficient condition for proof of a causal relationship between cattledriven nutrient redistribution and spatial distributions of topsoil nutrient stocks, since 'initial' conditions of soil nutrient distribution could principally also evoke a self-sustaining pattern of nutrient redistribution by cattle. However, this work presents further evidence for a role of grazers in creating these topsoil nutrient distribution patterns. Firstly, the pattern in the topsoil was unrelated $(\mathrm{N})$ or only weakly related $(\mathrm{P})$ to that at depth, in disagreement with a sustained initial nutrient distribution pattern. Secondly, the N/P ratio in the topsoil of the accumulation zone was significantly higher than in the depletion zone, in agreement with the higher N/P ratio of excreta (approx. 9) than of nutrient stocks in the soil $(<5)$. Thirdly, fluvial processes like runoff or interflow were minor factors in nutrient accumulation, since accumulation occurred mainly in the (flat) crest zone of the pasture.
$+1 \mathrm{~g} \mathrm{~N} \mathrm{~m}^{-3},-0.7$ to $+0.1 \mathrm{~g} \mathrm{P} \mathrm{m}^{-2}$; light grey (negative net transfer, causing depletion): -11 to $-7 \mathrm{~g} \mathrm{~N} \mathrm{~m}^{-2},-1.5$ to $0.7 \mathrm{~g} \mathrm{P} \mathrm{m}^{-2}$. The zones of depletion and accumulation were estimated from the net transfers of $\mathrm{N}$ and P: blocks in the lowest quartile of both $\mathrm{N}$ and $\mathrm{P}$ net transfer were assigned to the depletion zone; blocks inside the highest quartile of both $\mathrm{N}$ and $\mathrm{P}$ net transfer were assigned to the accumulation zone. Axes give Gauss-Krüger coordinates

Yet, there was some evidence for fluvial processes modifying the pattern, since elevated subsoil concentrations of $\mathrm{N}$ also occurred in the footslope of the pasture, where $\mathrm{N}$ returns by cattle were small.

The above relationships were apparent although nutrient transfers were small in comparison with the huge background of total nutrient stocks: total nutrient ingestion in the two grazing periods was equivalent to only $0.8 \%$ of $\mathrm{N}$ and $0.2 \%$ of $\mathrm{P}$ in 0 $60 \mathrm{~cm}$. Thus, the pattern of net nutrient transfers must have been conservative, working in the same direction over a long period of time, to evoke the observed pattern of topsoil nutrient stocks. That nutrient transfers were conservative was also supported by investigations of Auerswald et al. (2009), which demonstrated a close similarity of excreta distribution patterns in previous years and in different grazing periods within a year. That study also suggested topography as the main driver of excreta distribution in this paddock: animals preferred the flat parts like the terrace but especially the crest for resting, but used the entire pasture for grazing.

Although nutrient excretion was the main determinant of the pattern of net nutrient transfers, 
Table 6 Presence (+) and absence (-) of plant species in the nutrient accumulation and depletion zone of a pasture

\begin{tabular}{lll}
\hline Species & $\begin{array}{l}\text { Depletion } \\
\text { zone }\end{array}$ & $\begin{array}{l}\text { Accumulation } \\
\text { zone }\end{array}$ \\
\hline Arrhenatherum elatius L. & - & + \\
Galium mollugo L. & - & + \\
Geranium spec. & - & + \\
Ajuga reptans L. & + & - \\
Anthoxanthum odoratum L. & + & - \\
Cardamine pratensis L. & + & - \\
Cynosurus cristatus L. & + & - \\
Deschampsia caespitosa L. & + & - \\
Festuca rubra commutata L. & + & - \\
Holcus lanatus L. & + & - \\
Holcus mollis L. & + & - \\
Lathyrus pratensis L. & + & - \\
Plantago lanceolata L. & + & - \\
Ranunculus repens L. & + & - \\
Rumex crispus L. & + & - \\
Saxifraga granulata L. & + & - \\
Trifolium pratense L. & + & - \\
Trisetum flavescens L. & + & - \\
Urtica dioica L. & + & - \\
Veronica serpyllifolia L. & + & - \\
\hline Species & + & - \\
\hline
\end{tabular}

Species occurring in both zones: Achillea millefolium L.; Agropyron repens L.; Agrostis stolonifera L.; Agrostis tenuis L.; Alchemilla vulgaris L.; Alopecurus pratensis L.; Anthriscus sylvestris L.; Bellis perennis L.; Bromus mollis L.; Capsella bursa pastoris L.; Carum carvi L.; Cerastium holosteoides L.; Dactylis glomerata L.; Festuca arundinacea L.; Festuca pratensis L.; Heracleum sphondylium L.; Lamium album L.; Leontodon autumnalis L.; Lolium perenne L.; Phleum pratense L.; Poa annua L.; Poa pratensis L.; Poa supina L.; Poa trivialis L.; Ranunculus acris L.; Ranunculus ficaria L.; Rumex acetosa L.; Rumex obtusifolius L.; Stellaria graminea L.; Stellaria media L.; Taraxacum officinale L.; Trifolium dubium L.; Veronica agrestis L.; Veronica chamaedrys L.

differential ingestion patterns also contributed to spatial contrasts in net nutrient transfers. For instance, the larger $\mathrm{N}$ ingestion in the depletion zone contributed $17 \%$ to the difference in net transfer of $\mathrm{N}$ between the accumulation and depletion zone. The lesser nutrient ingestion in the accumulation zone must have resulted from its use as a campsite and the related high excreta density (Auerswald et al. 2009), fouling and trampling of herbage and consequent refusal by the cattle (Marsh and Campling 1970).
The closer relationship of topsoil than of deep nutrient stocks with the pattern of short-term nutrient transfers is also consistent with the nature of nutrient returns via excreta, which is superficial. This is particularly true for nutrients in dung which are bound to particulate organic matter and, thus, are less prone to infiltration and eventual leaching from the soil profile (Whitehead 2000). Other types of nutrient inputs, such as atmospheric $\mathrm{N}$ or litter deposition, also occur superficially. However, the return of nutrients by trampling of plants was likely also modified by the grazing cattle: residual biomass was much larger in the accumulation zone than in the depletion zone. This must have caused greater litterbound nutrient returns to the topsoil of the accumulation than of the depletion zone. This mechanism would also contribute to the grazer-driven contrast of topsoil nutrient contents between the depletion and accumulation zone.

The data present evidence for further factors modifying the topsoil distribution of $\mathrm{N}$. The $\mathrm{N}$ excess in the stock of the accumulation zone (relative to the depletion zone) was equivalent to 11 times that of the net nutrient transfer in two grazing periods, whereas that of $\mathrm{P}$ was 30 times greater. Thus, the $\mathrm{N}: \mathrm{P}$ ratio in the excess nutrient stock of the accumulation zone was about 3 , much smaller than the $\mathrm{N}: \mathrm{P}$ ratio in the (short-term) net nutrient transfer $(\sim 8)$. This discrepancy may be explained in terms of greater $\mathrm{N}$ losses by leaching and volatilization in the accumulation zone (e.g. Wachendorf et al. 2005) or greater biological nitrogen fixation in the depletion zone (e.g. Hansen et al. 2002) relative to the accumulation zone. Investigations by others in the same system (Flessa et al. 1996 and König 2000) or under similar conditions (Ball and Ryden 1984; Van der Meer and Whitehead 1990; Haynes and Williams 1993; Thornley et al. 1995; Schwinning and Parsons 1996; Loiseau et al. 2001), indicated that losses in the accumulation zone were far greater than gains by nitrogen fixation in the depletion zone.

$\mathrm{N}$ losses should have adverse effects on paddockscale net $\mathrm{N}$ transfer and pasture production, as herbage production was $\mathrm{N}$-limited (but not P-limited) throughout the pasture. Indeed, $\mathrm{N}$ limitation was clearly documented by the effect of top soil $\mathrm{N}$ on NNI, and effects of NNI on dry matter production and leaf area index. There was only one exception from this pattern: regrowth on fresh urine patches was not 


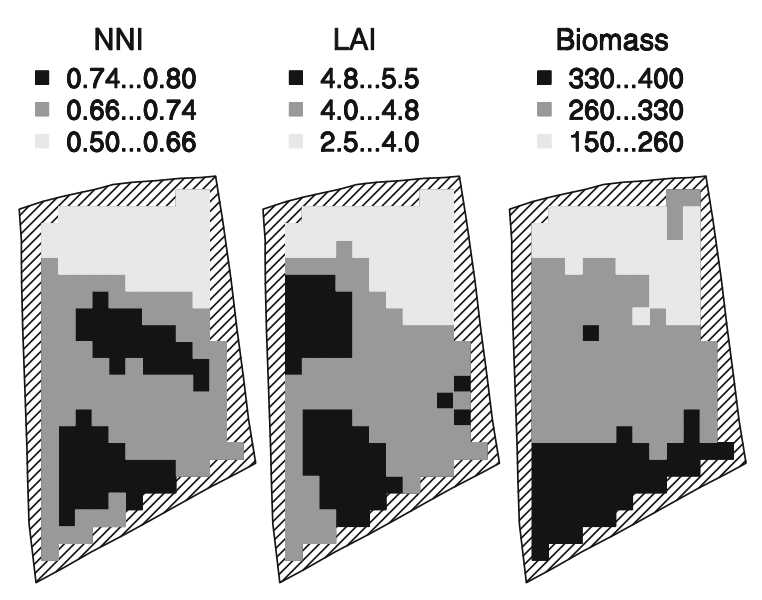

Fig. 5 Maps of Nitrogen Nutrition Index, NNI (left), and leaf area index, LAI (middle) and pre-gazing biomass, in g dry matter $\mathrm{m}^{-2}$ (right map) in 2nd growth. Different shades denote different ranges of values (see Figure for range associated with each class). Data were obtained by interpolation of data from 120 samples/measurements taken in a regular grid of $5 \times 10 \mathrm{~m}^{2}$ (see "Materials and methods")

limited by $\mathrm{N}$, but these areas accounted for only a few percent of the total pasture area (Auerswald et al. 2009). Although we did not perform a comprehensive study of small-scale $(<10 \mathrm{~m})$ variation of net nutrient transfers and soil nutrient stocks, it seemed evident from earlier work that $\mathrm{N}$ was mainly lost from fresh urine spots and these losses occurred in all parts of the pasture receiving urine (König 2000).

This work provides evidence for a strong effect of grazing cattle on topsoil $\mathrm{N}$ and $\mathrm{P}$ stock redistribution in an extensively managed pasture. These effects must have occurred via long-term stable patterns of ingested $\mathrm{N}$ and $\mathrm{P}$ transfers from zones of nutrient depletion to zones of nutrient accumulation. This interpretation, that transfers were long-term, was also supported by vegetation composition, which differed between the accumulation zone and the depletion zone. A. elatius L., G. mollugo L., and G. pratense L., present in the accumulation zone but absent from the depletion zone, are typical species of infrequently mown, fertile meadows (Ellenberg 1996). Conversely, C. cristatus L., D. caespitosa L., F. rubra commutata L., H. mollis L. and S. granulata L., present in the depletion zone but absent from the accumulation zone, are typical species of moderately nutrient poor, grazed grassland. Thus, long-term cattle-driven nutrient transfers also promoted species richness and distribution patterns at the paddock scale.
Acknowledgments This research was part of the research network "Forschungsverbund Agrarökosysteme München" (FAM). It was supported by the Federal Ministry for Education and Research (BMBF), Berlin, Germany (Project No. BMBF 0339370) and the Bavarian State Ministry for Education, Culture, Science and Art. Ulrike Schütz, Dr. Katharina Stroh, Erna Eschenbach, Josef Bauer, Hans Vogl and Fritz Mädl are thanked for manifold assistance. Two reviewers provided helpful comments.

\section{References}

Arnold GW (1981) Grazing behaviour. In: Morley FHW (ed) Grazing animals. World animal science. Amsterdam, Elsevier, pp 79-104

Auerswald K, Mayer F, Schnyder H (2009) Coupling of spatial and temporal pattern of cattle excreta patches on a low intensity pasture. Nutr Cycl Agroecosyst. doi:10.1007/ s10705-009-9321-4

Augustine DJ (2003) Long-term, livestock-mediated redistribution of nitrogen and phosphorus in an East African savanna. J Appl Ecol 40:137-149

Augustine DJ, Frank DA (2001) Effects of migratory grazers on spatial heterogeneity of soil nitrogen properties in a grassland ecosystem. Ecology 82:3149-3162

Ball PR, Ryden JC (1984) Nitrogen relationships in intensively managed temperate grasslands. Plant Soil 76:23-33

Braun-Blanquet J (1964) Pflanzensoziologie. Springer, Wien

Burke IC (1999) Spatial variability of soil properties in the shortgrass steppe: the relative importance of topography, grazing, microsite, and plant species in controlling spatial patterns. Ecosystems 2:422-438

Clark FE (1977) Internal cycling of nitrogen in shortgrass prairie. Ecology 58:1322-1333

Duru M, Ducroq H (1997) A nitrogen and phosphorus herbage nutrient index as a tool for assessing the effect of $\mathrm{N}$ and $\mathrm{P}$ supply on the dry matter yield of permanent pastures. Nutr Cycl Agroecosys 47:59-69

Duru M, Lemaire G, Cruz P (1997) Grasslands. In: Lemaire G (ed) Diagnosis of the nitrogen status in crops. Springer, Berlin, pp 59-72

Ellenberg H (1996) Vegetation Mitteleuropas mit den Alpen: In ökologischer, dynamischer und historischer Sicht. Universitätstaschenbücher, Stuttgart

Flessa HP, Dörsch F, Beese F, König H, Bouwman AF (1996) Influence of cattle wastes on nitrous oxides and methane fluxes in pasture land. J Environ Qual 25:1366-1370

Floate MJS (1981) Effects of grazing by large herbivores on nitrogen cycling in agricultural ecosystems. In: Clark FE, Rosswall T (eds) Terrestrial nitrogen cycles; processes, ecosystem strategies and management impacts. Ecological Bulletin 33, Stockholm, pp 585-601

Gillingham AG, Tillman RW, Gregg PEH, Syers JK (1980) Uptake zones for phosphorus in spring by pasture on different strata within a hill paddock. New Zeal J Agric Res 23:67-74

Hansen EM, Hogh-Jensen H, Djurhuus J (2002) Biological nitrogen fixation in a grazed perennial grass/clover ley and correlation with herbage and soil variables. Eur $\mathbf{J}$ Agron 16:309-320 
Hartge KH, Horn R (1989) Die physikalische Untersuchung von Böden. Ferdinand Enke Verlag, Stuttgart 2. Auflage

Haynes RJ, Williams PH (1993) Nutrient cycling and soil fertility in the grazed pasture ecosystem. Adv Agron 49:119-199

Hirata M, Sugimoto Y, Ueno M (1987) Distribution of dung pats and ungrazed areas in Bahiagrass (Paspalum notatum Flügge) pasture. J Japan Soc Grassland Sci 33:128-139

Jenny H (1980) The soil resource: origin and behavior. Springer, New York

Jewell PL, Käuferle D, Güsewell S, Berry NR, Kreuzer M, Edwards PJ (2007) Redistribution of phosphorus by cattle on a traditional mountain pasture in the Alps. Agric Ecosys Environ 122:377-386

König H (2000) Stickstoffdynamik und Pflanzenbestandsentwicklung einer extensiv bewirtschafteten Hangweide. $\mathrm{PhD}$ thesis, Technische Universität München, Germany

Lemaire G, Gastal F (1997) Nitrogen uptake and distribution in plant canopies. In: Lemaire $G$ (ed) Diagnosis of the nitrogen status in crops. Springer, Berlin, pp 3-43

Lemaire G, Salette J (1984) Relation entre dynamique de croissance et dynamique de prélèvement d'azote pour un peuplement de graminées fourragères. I. Etude de l'effet du milieu. Agronomie 4:423-430

Loiseau P, Soussana JF, Louault F, Delpy R (2001) Soil N contributes to the oscillations of the white clover content in mixed swards of perennial ryegrass under conditions that simulate grazing over five years. Grass Forage Sci 56:205-217

Marini L, Scotton M, Klimek S, Isselstein J, Pecile A (2007) Effects of local factors on plant species richness and composition of Alpine meadows. Agric Ecosys Environ 119:281-288

Marsh R, Campling RC (1970) Fouling of pastures by dung. Herb Abstr 40:123-130

Risser PG, Parton WJ (1982) Ecosystem analysis of the tallgrass prairie: nitrogen cycle. Ecology 63:1342-1351
Rotz CA, Taube F, Russelle MP, Oenema J, Sanderson MA, Wachendorf M (2005) Whole-farm perspectives of nutrient flows in grassland agriculture. Crop Sci 45:21392159

Rowarth JS, Tillman RW, Gillingham AG, Gregg PEH (1992) Phosphorus balances in grazed, hill-country pastures: the effect of slope and fertiliser input. New Zeal J Agric Res 35:337-342

Schwinning S, Parsons AJ (1996) A spatially explicit population model of stoloniferous $\mathrm{N}$-fixing legumes in mixed pasture with grass. J Ecol 84:815-826

Sinowski W, Auerswald K (1999) Using relief parameters in a discriminant analysis to stratify geological areas of different spatial variability of soil properties. Geoderma 89:113-128

Thornley JHM, Bergelson J, Parsons AJ (1995) Complex dynamics in a carbon-nitrogen model of a grass-legume pasture. Ann Bot 75:79-94

Van der Meer HG, Whitehead DC (1990) The fate of nitrogen in animal excreta applied to grassland. CABO Report 14. Centre for Agrobiological Research, Wageningen

VdLUFA (1991) Handbuch der landwirtschaftlichen Versuchsund Untersuchungsmethodik. VdLUFA-Verlag, Darmstadt

Wachendorf C, Taube F, Wachendorf M (2005) Nitrogen leaching from ${ }^{15} \mathrm{~N}$ labelled cow urine and dung applied to grassland on a sandy soil. Nutr Cycl Agroecosys 73:89-100

Webster R (1985) Quantitative spatial analysis of soil in the field. Adv Soil Sci 3:1-70

White SL, Sheffield RE, Washburn SP, King LD, Green JT (2001) Spatial and time distribution of dairy cattle excreta in an intensive pasture system. J Environ Qual 30:21802187

Whitehead DC (2000) Nutrient elements in grassland. CABI Publishing, Wallingford

Williams PH, Haynes RJ (1990) Influence of improved pastures and grazing animals on nutrient cycling within New Zealand soils. New Zeal J Ecol 14:49-57 